\title{
Correction to: Schistosoma haematobium infection morbidity, praziquantel effectiveness and reinfection rate among children and young adults in Gabon
}

\author{
Jean Claude Dejon-Agobé ${ }^{1,2^{*}} \mathbb{D}$, Jean Ronald Edoa' ${ }^{1}$, Yabo Josiane Honkpehedji ${ }^{1,3}$, Jeannot Fréjus Zinsou ${ }^{1,3}$, \\ Bayodé Roméo Adégbitè ${ }^{1}$, Mirabeau Mbong Ngwese ${ }^{1}$, Ance Mangaboula ${ }^{1}$, Bertrand Lell ${ }^{1,4,5}$, \\ Tamirat Gebru Woldearegai ${ }^{5,6}$, Martin Peter Grobusch ${ }^{1,2,5}$, Benjamin Mordmüller ${ }^{5}$ and \\ Ayôla Akim Adegnika 1,3,5
}

\section{Correction to: Parasites Vectors (2019) 12:577 https://doi.org/10.1186/s13071-019-3836-6} Following publication of the original article [1], it was brought to our attention that Tamirat Gebru Woldearegai had not been added to the author list. The data published in this manuscript came from work carried out within the framework of a consortium of which Tamirat Gebru Woldearegai was a member, and so TGW should be included in the author list.

The author list has been corrected in the original article and the updated author list may be found in this correction. In addition, in relation to this correction, the Author Contributions statement has been updated as follows:

"JCDA performed clinical investigation, formal analysis, and wrote the original draft. JRE, YJH, JFZ and BRA performed clinical investigations. MN wrote the original draft of the laboratory methods. AM performed the study area map (Fig. 1). BL validated the statistical analysis. MPG supervised the study conduct. TGW, BM and AAA conceptualized the study design, and supervised

The original article can be found online at https://doi.org/10.1186/s13071 019-3836-6.

*Correspondence: jcagobe@gmail.com

${ }^{1}$ Centre de Recherches Médicales de Lambaréné, Lambaréné, Gabon

Full list of author information is available at the end of the article the study conduct. All authors contributed to the writing of the manuscript. All authors read and approved the final manuscript."

The authors apologize for any inconvenience caused.

\section{Author details}

${ }^{1}$ Centre de Recherches Médicales de Lambaréné, Lambaréné, Gabon. ${ }^{2}$ Center of Tropical Medicine and Travel Medicine, Department of Infectious Diseases, Division of Internal Medicine, Amsterdam University Medical Centers, Location AMC, University of Amsterdam, Amsterdam, The Netherlands. ${ }^{3}$ Department of Parasitology, Leiden University Medical Center, Leiden, The Netherlands. ${ }^{4}$ Division of Infectious Diseases and Tropical Medicine, Department of Medicine 1, Medical University of Vienna, Vienna, Austria. ${ }^{5}$ Institut für Tropenmedizin, Eberhard Karls Universität Tübingen, Partner Site, Tübingen, Germany.

${ }^{6}$ German Center for Infection Research, Tübingen, Germany.

Published online: 21 June 2021

\section{Reference}

1. Dejon-Agobé JC, Edoa JR, Honkpehedji YJ, Zinsou JF, Adégbitè BR, Ngwese MM, Mangaboula A, Lell B, Woldearegai TG, Grobusch MP, Mordmüller B, Adegnika AA. Schistosoma haematobium infection morbidity, praziquantel effectiveness and reinfection rate among children and young adults in Gabon. Parasites Vectors. 2019;12:577. https://doi.org/10. 1186/s13071-019-3836-6.

\section{Publisher's Note}

Springer Nature remains neutral with regard to jurisdictional claims in published maps and institutional affiliations.

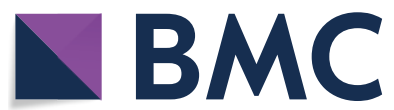

(c) The Author(s) 2021. This article is licensed under a Creative Commons Attribution 4.0 International License, which permits use, sharing, adaptation, distribution and reproduction in any medium or format, as long as you give appropriate credit to the original author(s) and the source, provide a link to the Creative Commons licence, and indicate if changes were made. The images or other third party material in this article are included in the article's Creative Commons licence, unless indicated otherwise in a credit line to the material. If material is not included in the article's Creative Commons licence and your intended use is not permitted by statutory regulation or exceeds the permitted use, you will need to obtain permission directly from the copyright holder. To view a copy of this licence, visit http://creativeco mmons.org/licenses/by/4.0/. The Creative Commons Public Domain Dedication waiver (http://creativecommons.org/publicdomain/ zero/1.0/) applies to the data made available in this article, unless otherwise stated in a credit line to the data. 